\title{
THE IMPACT OF SPORT ON THE OVERALL STANDARD OF SATISFACTION OF STUDENTS WITH PHYSICAL DISABILITIES
}

\author{
Flóra Bergendiová, Dušana Čierna
}

Department of Sport Educology and Sport Humanities, Faculty of Physical Education and Sport, Comenius

\section{University in Bratislava}

\begin{abstract}
Summary: Life satisfaction is the main goal that people try to achieve in their lives. This study aims to broaden the knowledge of overall life satisfaction of physically handicapped students performing sports. The Satisfaction with Life scale was used to assess the overall life satisfaction SWLS and Emotional Habitual Subjective Well-Being questionnaire SEHP. The research sample consisted of 25 physically handicapped students. Based on their performance in physical education and sport they were divided into 2 groups: regularly active in sports (36\%) and occasionally active in sports (64\%). The results showed at an interesting fact, $66 \%$ of regularly active students in sports with a physical handicap were found on the high level of life satisfaction (44\%) and extremely high level of life satisfaction (22.2\%), comparing to occasionally active students in sports, who supported only $18.8 \%$ of the particular category. $12.5 \%$ of occasionally active students in sports feel physical vigour, mainly after coming from physiotherapy and after getting enough sleep. Regularly active peers in sports feel physical vigour while performing physical education and sports or after finishing the activity. His spare time is devoted to fitness activities, swimming, table tennis and shooting.
\end{abstract}

Key words: life satisfaction, a physically handicapped student, doing sport

DOI 10.1515/afepuc-2017-0005

(C) Acta Facultatis Educationis Physicae Universitatis Comenianae 


\section{Introduction}

In general, the concept of satisfaction is a subjective criterion of a positive evaluation of various events, conditions of activities and objects, including one, perceiving as a pleasant joyful and successful experience for foregoing work (Strmeň \& Raiskup 1998). Křivohlavý (2001) states that under the influence circumstances, time and experience subjective point of view on life satisfaction is changed. Some authors, such as Diener, Suhand \& Oishi (1997) note that life satisfaction is based on comparison to the standard, which is created by each individual and therefore it is not appropriate to measure it based on objective external criteria. "What makes a person satisfied in one's life is depends on one's personal perceptions. Life satisfaction is based on the positive evaluation of conditions of one's life which individual evaluates with favour towards his standards and expectations. According to Diener and Ryan (2009), life satisfaction is being perceived as a term evaluating people `s lives from a broader perspective and belonging to a cognitive category and happiness to affective one. From this perspective, happiness is understood as a broader concept of subjective wellbeing. Kim and Hatfield (2004) agree with a statement that subjective wellbeing is made of two components: emotions or the presence of positive emotions and absence of negative emotions and subjective evaluation of one's own life. Grob (1998) states that a term subjective life satisfaction includes happiness, satisfaction with life, but on the other hand it points out to low self-confidence, low satisfaction or negative sides of life. According to Haybron (2005), satisfaction of an individual depends on various factors which are expressed by a following equation $\mathrm{S}=\mathrm{K}+\mathrm{O}+\mathrm{V}$, where $\mathrm{S}$ equals satisfaction, i.e. permanent extent of happiness, $\mathrm{K}$ equals constitution which represents an inherited side of overall happiness and disposition to experiencing the happiness. $\mathrm{O}$ equals to peculiarities of life and $\mathrm{V}$ equals to factors that are controlled by our mind. Beside of the proceeding factors, a state of happiness of a particular individual appears as a very important indicator of life satisfaction and happiness. The Health status plays an important role in evaluating one's own life and mainly at higher age and among physically handicapped persons. Kř́žová (2005) claims that people who are not satisfied with their health status are not also satisfied with their other areas of their life and also agrees with the fact that the evaluation of one's own health can be much more difficult, if it is also related to a disability which keeps a person from doing everyday activities in their ordinary lives.

Moreover, Kebzy \& Šolcova (2005) say that subjective assessment of a health status is closely related to one's wellbeing. Their research has pointed at the interesting fact, thus the 
health status is one of the strongest indicators of satisfaction with their own life. This feeling of happiness is also related to the subjective assessment of the health status. Furthermore, they note that happiness is just one significant part of complex personal wellbeing which might include joy, elevation, serenity and mental balance.

They think that people are the happiest when they can devote their time to their favorite activities. Human happiness and life satisfaction is influenced by psychological and social effects. However, the literature mentions also the third dimension. Defining body and physical and fitness represents another important component in our life contributing to a feeling of happiness and wellbeing. Moreover, it is also important to consider either the impact of movement activity which has a long-term effect or a short-term effect on our selfassessment. Physical activity according to Kebzy and Šolcová (2003) influences the level of self-esteem, anxiety, depression and stress. This statement has been supported several times by various surveys, conducted either on healthy and ill persons or adults and adolescents. Therefore the feeling of happiness and satisfaction can be described as satisfaction with one`s physical fitness. Researches that have been conducted into sport psychology in the last ten years reported that children who were in their early school life more active in physical education and sports had better self-assessment. This fact, accordingly stresses the importance of the organized physical education and sport activity and its crucial place in child `s life.

The aim of the study was to broaden the knowledge of overall life satisfaction of physically handicapped students through performing sports

\section{Methods}

The research sample consisted of 25 physically handicapped students of Secondary vocational school on Mokrohajska Street in Bratislava. $68 \%$ of the participants involved in the research were boys and $32 \%$ girls. Based on sports, they were divided into two groups; the first one was formed of physically handicapped students who are regularly active in their free time (36\%); the second group consisted of physically handicapped students who are occasionally active in physical education and sport (64\%). The youngest respondent was 17 years old and the oldest one 24 years old, while the average age of respondents was 19.2 years old. All respondents suffer from a handicap, $84 \%$ have a congenital disorder and $16 \%$ of respondents inherited the disability during their life. The standardized questionnaire - The Satisfaction with Life Scale SWLS was applied to assess overall life satisfaction (Diener et al. 
1985). The Satisfaction with Life Scale is aimed at assessing the overall life satisfaction and contains five components.

The respondents commented on their agreement or disagreement on a particular statement regarding to various components using a 7-point Lickert scale. The components of the Lickert scale are mostly of a global nature than a specific nature. The individual points on the scale express following opinions: 1-strongly disagree, 2-disagree, 3-disagree somewhat,4neither disagree nor agree, 5-agree somewhat, 6-agree, 7-strongly agree. Based on the responses, it is possible to achieve $1-7$ points. Assigning value to score $5-7$ equals a higher level of life satisfaction, assigning value 4 equals neutral satisfaction and assigning $1-3$ points means a lower level of lie satisfaction. The overall dimension of life satisfaction can reach values in the range of $5-35$; score falling within the interval $5-9$ represents strong disagreement, interval $10-14$ disagreement, score within $15-19$ points at partial disagreement, interval $20-24$ represents partial life satisfaction, internal $25-29$ includes individual who are very satisfied with their life, score 30 and above tell about extremely high life satisfaction (Diener et al. 1985).

Another research method that was used to obtain empirical data was Emotional Habitual Subjective Well-Being questionnaire. It is a brief instrument aimed at measuring subjective well-being which differentiates between positive and negative side of experiencing various feelings and at the same time integrates the physical feelings. It does not measure the intensity of experiencing current emotions but it aims to find out the frequency of experiencing of individual states in a long-term interval which authors of this questionnaire divided into positive and negative zone. The positive feelings are divided into: delight, physical strength, joy and happiness. The negative emotions are: anger, a feeling of blame, shame, fear, pain and sadness. The questionnaire consists of 10 components, where the respondents were supposed to comment the frequency of experiencing the concrete emotions on a six-grade scale (almost never, rarely, sometimes, often, very often, almost always) (Džuka \& Dalbert 2002). The available results were processed applying basic mathematical statistical methods and described using basic logical methods. Mann-Whitney U-test was applied to compare overall life satisfaction and subjective well-being among regularly active students and occasionally active students in sports (among boys and girls). The results were described using percentages and graphs which were applied in order to provide better orientation. 


\section{Results and Discussion}

Assessment of overall life satisfaction level of physically handicapped students from a sport perspective did not bring statistically significant differences. However, the results show (Figure 1) that $66 \%$ of regularly active physically handicapped students in sports were found in the zone of high (44.4\%) and extremely high (22.2\%) life satisfaction comparing to occasionally active students in sports who assigned this category only to $18.8 \%$. $33.4 \%$ of regularly active students and $31.3 \%$ of occasionally active students are partially satisfied with their life. $6.2 \%$ of occasionally active students are found in the zone of life dissatisfaction and $6.2 \%$ of extremely high life dissatisfaction. Significant difference can be seen in the component among regularly active and occasionally active physically handicapped students, where they can comment the statement "My life is in many aspects close to my ideal". $55.4 \%$ of regularly active students agreed (44.2\%) or strongly agreed (11.2\%), while a positive attitude of occasionally active students was evidenced in much lower percentage $-18.8 \%$ of agreement and only $6.4 \%$ strongly agreed with the statement. Regarding to life conditions, regularly active students have a positive attitude; $33.3 \%$ somewhat agree, $33.3 \%$ agree and $33.3 \%$ strongly agree that life conditions are excellent. A negative attitude of occasionally active students was noted, even though they had similar comments (31.4\%). $44.3 \%$ of physically handicapped students who are regularly active in physical education and sports were fully satisfied with their life. Much lower part (12.3\%) of occasionally active students agreed with that statement. A similar research was conducted by Porvarðardóttir (2014) from Reykjavik University, which investigated physically handicapped adolescents and their overall life satisfaction. Research sample consisted of 628 physically handicapped students from secondary schools in Iceland. $39.1 \%$ of respondents stated that they were fully satisfied with their life, $39.4 \%$ were partially satisfied, $15.2 \%$ were dissatisfied with their living conditions and $6.4 \%$ were fully disappointed. $33.3 \%$ of regularly active students and $37.6 \%$ of occasionally active students agreed with the statement that they have already achieved important things in their life which they were supposed to gain. $44.5 \%$ of occasionally active students and $18 \%$ of respondents of a second group had a neutral attitude. In the last component physically handicapped students were able to comment on their agreement or disagreement with the statement "If I had lived again, I wouldn't have changed anything". $75.1 \%$ of occasionally active students strongly disagreed, while $44.3 \%$ of regularly active students strongly disagreed. 


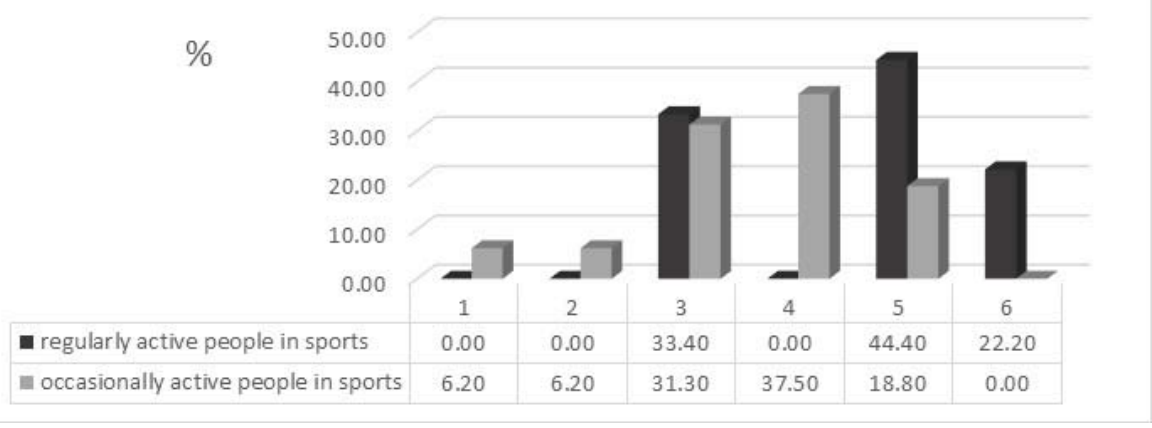

Legend: 1. extremely high life dissatisfaction 2. life dissatisfaction 3. slight life dissatisfaction 4. partial life satisfaction 5. high life satisfaction 6. extremely high life satisfaction

Figure 1

Percentage of overall life satisfaction of physically handicapped students from a sport perspective

The second part of the results give evidence about emotional subjective well-being or the frequency of experiencing individual positive and negative statuses in a long-term interval of physically handicapped students from a sport perspective. Statistically significant differences were not shown when comparing results of frequency of experiencing anger among regularly and occasionally active students in sports. $55.6 \%$ of regularly active and 50 $\%$ of occasionally active students in sports sometimes experience anger. Family fights, irresponsibility of doctors and undoubtedly the restrictions are considered to be the most common reason of experiencing this feeling which impedes them of performing their daily routine.

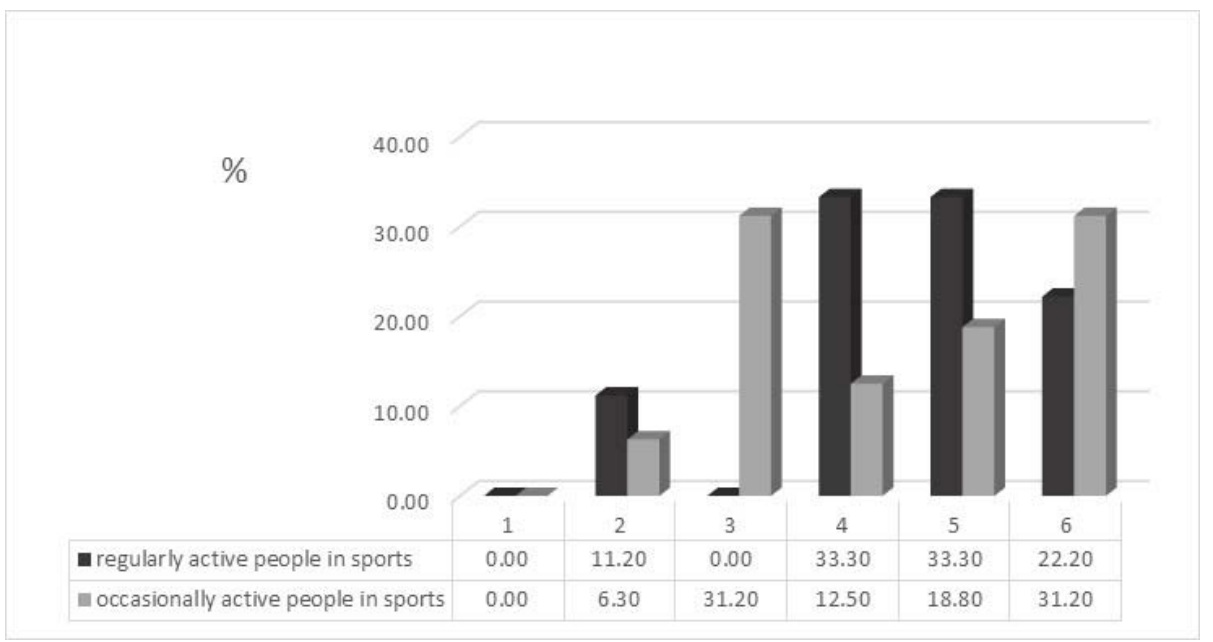

Legend: 1. almost always 2. very often 3. often 4. sometimes 5. rarely 6. nearly never Figure 2

A Percentage frequency of experiencing a feeling of blame among physically handicapped students from a sport perspective 
The figure 2 shows that $31.2 \%$ of occasionally active students with a physical handicap often feel blamed, while $6.3 \%$ feel blamed very often; the fact they stated that they rarely $(18.8 \%)$ or nearly never $(31.2 \%)$ have such a feeling is very pleasant. Students who stated that they often felt blamed, said they felt blame mainly because what they had done in the past or because of the people blaming them of something. Although, the research sample consists of physically handicapped students who are being restricted in all fields of their life, we were pleased by results of their savouring of delight where more than a half of respondents (55.6\% of regularly active in sports and $62.5 \%$ of occasionally active in sports) stated they felt delighted very often and mainly when spending their time doing the activities which they enjoy. Besides doing sports they like reading books, watching documentaries and series (mostly in English), listening to music of various music genres. Girls prefer cooking, singing and writing stories and reflections on a real life. On the other hand boys prefer PC games and repairing computers. Results show that $22.2 \%$ of regularly active respondents in sports nearly never savour delight. They state that the activities they perform are too "ordinary". When evaluating other conditions, we came to the conclusion that one third of respondents regardless of them being regularly or occasionally active in sports feel often ashamed or be embarrassed very often. Others say that they try not to be ashamed of themselves and be proud of what they achieved in their life despite their handicap. Based on result evaluation it can be concluded that $12.5 \%$ of occasionally active students with a physical handicap always feel physical vigour when performing physical education and a sport activity or after coming back from physiotherapy and getting enough sleep. Regularly active peers state that they savour physical vigour when performing physical education and a sport activity or after completing those activities. In their free time they do fitness, go swimming, cycling, play table tennis or do sport shooting. The main reason why they did not savour the physical vigour was a pain of different kinds.

Results in differences of experiencing anger frequency from a sport perspective were not statistically significant, but they pointed at considerable difference of a gender perspective. While boys rarely experience anger, girls often do. The reasons of frequent experiencing anger include: fear of one`s health, fear of doctors and a hospital, fear of new things, fear of disappointment and rejection from other people (Table 3 ). 


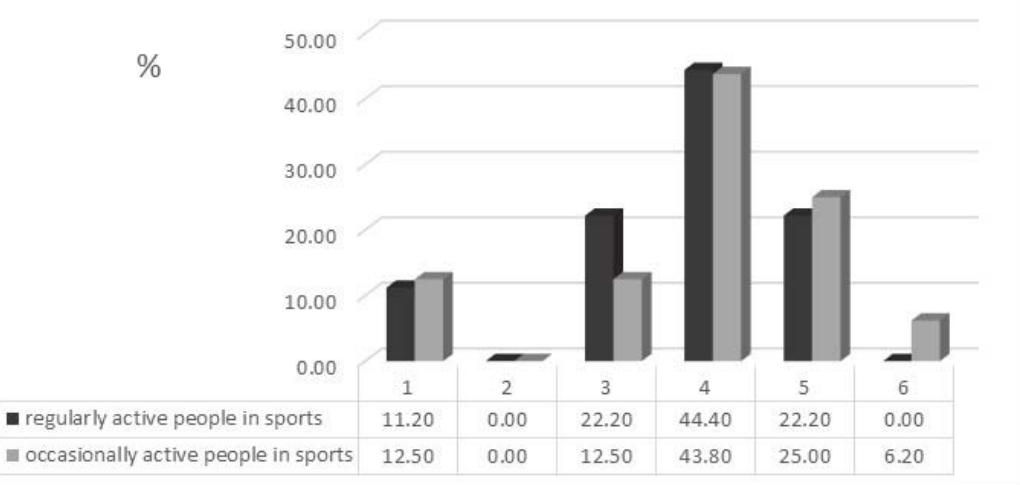

Legend: 1. almost always 2. very often 3. often 4. sometimes 5. rarely 6. nearly never

Figure 3

A percentage frequency of experiencing physical vigour of physically handicapped students from a sport perspective

As in the previous case, the frequency of experiencing the pain from a gender perspective also brought statistically significant differences (Table 4). Boys rarely go through it, while girls feel it more often. $66.6 \%$ of regularly active students sometimes feel it, $11.2 \%$ rarely experience the pain and $22.2 \%$ nearly never. $37.6 \%$ of occasionally active students in sports feel the pain very often. Experiencing pain is interconnected with experiencing sadness. From the total number of occasionally active students in sports $18.8 \%$ stated they were often sad and $6.2 \%$ said that almost always. The majority (66.6\%) of regularly active students in sports with a physical handicap rarely feel sad. The most serious reasons for feeling sad were the memories of the past, loss of a close relative and not being accepted by other people.

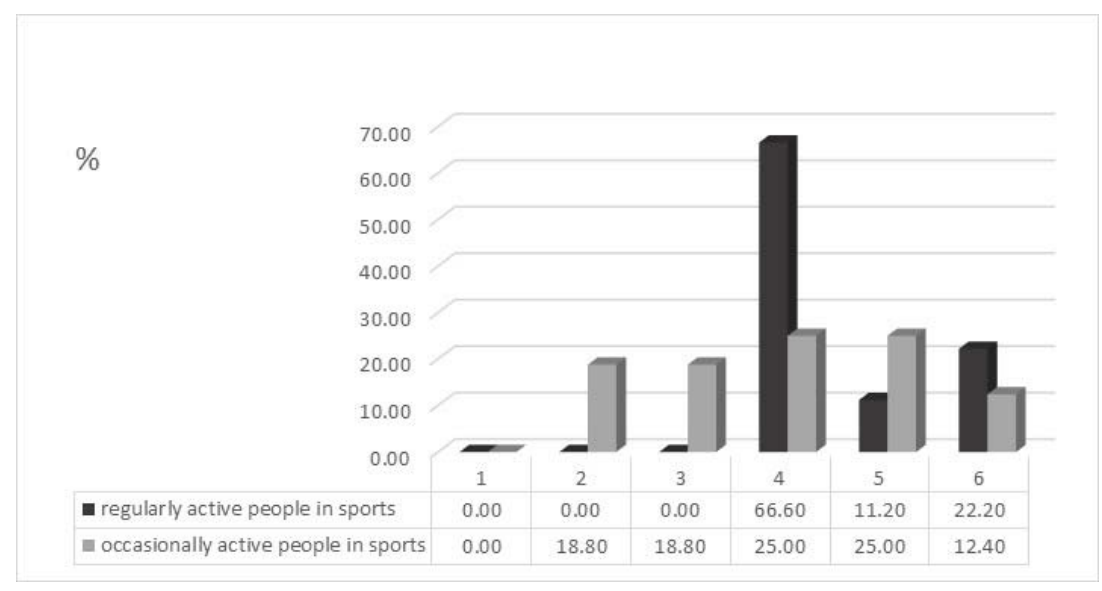

Legend: 1. almost always 2. very often 3. often 4. sometimes 5. rarely 6. nearly never

Figure 4

A percentage frequency of experiencing pain of physically handicapped students from a sport perspective 
$78 \%$ of regularly active and $87.5 \%$ of occasionally active students in sports often experience happiness or very often or almost always in similar percentage ( $78 \%$ of regularly active and $68.8 \%$ of occasionally active). Joy and happiness are being experienced when spending time with their family and friends, going for a walk with a dog or being successful after having achieved something. $12.4 \%$ of occasionally active students in sports reported feeling happy rarely or nearly never (Table 5, Table 6).

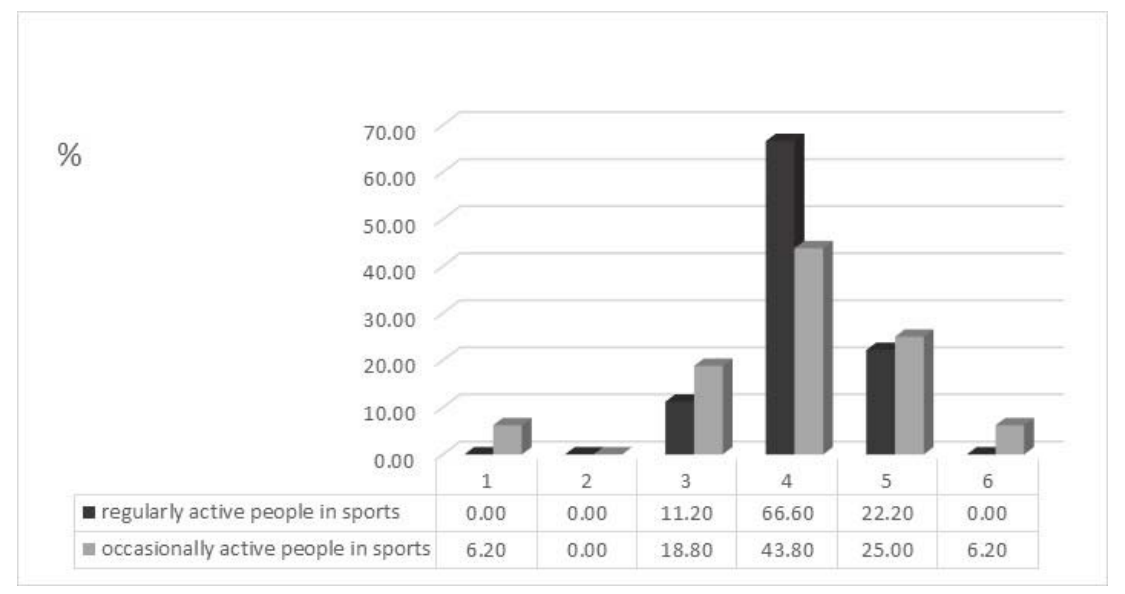

Legend: 1. almost always 2. very often 3. often 4. sometimes 5. rarely 6. nearly never Figure 5

A percentage frequency of experiencing grief of physically handicapped students from a sport perspective

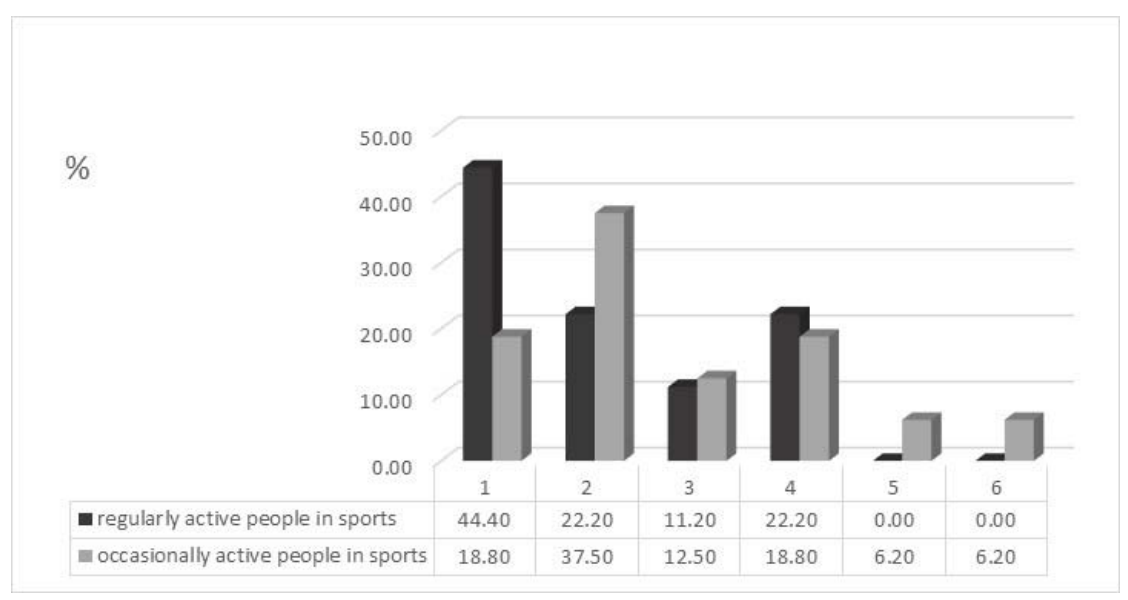

Legend: 1. almost always 2. very often 3. often 4. sometimes 5. rarely 6. nearly never Figure 6

A percentage frequency of experiencing happiness of physically handicapped students from a sport perspective

\section{Conclusions}

Based on the gained results, we can conclude: 
- $\quad 66.6 \%$ of regularly active students in sports with a physical handicap are found in the area of high (44.4\%) up to extremely high (22.2\%) life satisfaction comparing to occasionally active in sports who in $18.8 \%$ supported the particular category.

- $\quad 44.3 \%$ of physically handicapped students who regularly perform physical education and sports are fully satisfied with their life. A much lower part (12.3\%) of occasionally active students in sports agreed with a following statement.

- Family fights, irresponsibility of doctors and restrictions are one from the most common reasons of experiencing anger which impede students of doing their daily routine.

- $\quad 55.6 \%$ of regularly active and $62.5 \%$ of occasionally active students in sports state that they often or very often or almost always feel delighted, especially when they can devote their time to activities which they enjoy. Besides doing sports in their free time, they like reading, watching documentaries, listening to music. While girls like cooking, singing and writing stories, boys prefer playing PC games and repairing computers.

- $\quad 12.5 \%$ of occasionally active students in sports with a physical handicap feel almost always physical vigour, mostly after coming back from a physiotherapy centre; regularly active peers in sports stated that they felt physically fit when performing physical education and a sport activity or after completing it. In their free time they mostly do fitness, go swimming, cycling, table tennis or sport shooting.

- Fear of one`s health, fear of doctors and a hospital, fear of new things, fear of disappointment belong to the reasons of frequent experiencing fear.

- From occasionally active students $18.8 \%$ are often sad and $6.2 \%$ feel sad almost always. The majority $(66.6 \%)$ of regularly active students in sports with a physical handicap sometimes experience grief.

- $\quad$ On the other hand, $78.8 \%$ of regularly active students in sports often experience joy, very often or almost always and go through a feeling of happiness in similar percentage (78.0 $\%$ of regularly active in sports and $68.8 \%$ of occasionally active in sports).

\section{References}

1. DIENER, E. et al., 1985. The satisfaction with life scale. In: Journal of Personality Assessment. 49: 71-75.

2. DIENER, E. \& K. RYAN, 2009. Subjective well-being: a general overview. South African Journal of Psychology. 39(4): 391-406.

3. DIENER, E., E. SUH \& S. OISHI, 1997. Recent findings on subjective well-being. Indian Journal of Clinical Psychology. 24: 25-41. 
4. DŽUKA, J. \& C. DALBERT, 2002. Vývoj a overenie validity škál emocionálnej habituálnej subjektívnej pohody (SEHP). In: Československá psychologie. XLVI(3): 234250.

5. GROB, A., 1998. Adolescents'subjective well-being in fourteen cultural contexts. In: J.-E. NURMI (Ed.) Adolescents, cultures and conflicts: Growing up in contemporary Europe. New York: Garland Publishing.

6. HAYBRON, D. M., 2005. Life satisfaction, Ethical Reflection, and the Science of Happiness. Department of Philosophy, Saint Luis University.

7. KEBZA, V., ŠOLCOVÁ, I., 2005 Osobní pohoda: determinujícího faktory u české dospělé populace. In: BLATNÝ, M. ed. a kol.: Psychosociální souvislosti osobní pohody. Brno: Masarykova Univerzita.

8. KEBZA, V. \& I. ŠOLCOVÁ, 2003. Well-being jako psychologicky a zároveň meziodborově založený pojem. Československá psychologie. 47(4): 333-345.

9. KŘIVOHLAVÝ, J., 2001. Psychologie zdraví. Praha: Portál.

10. KŘÍŽOVÁ, E. 2005. Sociologické podmínky kvality života. In: PAYNE, J a kol.: Kvalita života a zdraví. Praha: Triton.

11. STRMEŇ, L. \& J. CH. RAISKUP, 1998. Výkladový slovník. Bratislava: Iris.

12. KIM, J. \& E. HATFIELD, 2004. Love types and subjective well being. Social Behavior and Personality: An International Journal. 32: 173-182.

13. Potvarðardóttir, E., 2014. Adolescents with Physical Disabilities and Their Wellbeing and Peer Relationships Within Secondary Schools in Iceland http://skemman.is/stream/get/1946/19427/44365/1/BSc_ritger\%C3\%B0_pdf.pdf 